\title{
HAGEMEYER, Rafael Rosa. Historia \& Audiovisual. Belo Horizonte: Autêntica Editora, 2012.
}

\author{
Maria da Conceição Francisca Pires
}

\section{Resenhas}

Por vários anos nós, historiadores que privilegiamos a análise dos registros visuais como testemunhos da história, acontecimentos ou de experimentos, nos preocupamos em iniciar nossos estudos defendendo a pertinência destes como fontes documentais e a importância de se identificar os significados que neles se constituem para além daquilo que é dado a ver.

Com os filósofos, antropólogos, cientistas sociais, buscávamos argumentar sobre as frestas abertas pela força das imagens e acerca das suas possibilidades discursivas para além das palavras, estas últimas também signos a serem reconhecidos e decifrados. Era imprescindível tirá-las do recalque a que tinham sido levadas pela história e, como Walter Benjamin, reconhecê-las como uma epifania da verdade.

No transcurso da construção desse objeto, discutir os elementos agregados às imagens se mostrou fundamental para a sua compreensão de forma mais ampla. Tornou-se imperativo contemplar as diferentes sonoridades produzidas em conjunto com as imagens para prover silêncios existentes, os códigos linguísticos e sígnicos empregados para presentificar ausências, os diferentes suportes utilizados para Ihes conferir tangibilidade, as plurais intencionalidades humanas que construíram as representações para cativar e convencer a platéia sobre aquilo que é visto e ouvido. Tudo isso, sem descuidar do fato de que tudo isso movimenta o "museu imaginário" individual daquele que durante o "ato de espreitamento" abordado por Certeau (1994) vê enquanto ouve, sente enquanto olha, pensa enquanto sente.

Renovaram-se as questões a serem colocadas, agora não só para os registros visuais, mas também para os audiovisuais que para além dos olhos nos afetam os ouvidos (e porque não dizer, os outros sentidos). Os registros audiovisuais contemporâneos extremizam o ideal romano de arte. Buscam ser a cópia mais que perfeita não só do que existe, mas do possível ainda inexistente. No exercício de unir som e imagem, mostram-se capazes de abandonar a eloquência discursiva das palavras e nos emudecer, ou ainda de produzir sons para desdizer, sem contribuir para a efetivação do diálogo no interior de uma dada audiência.

É sobre esse complexo produtor de sentidos que se dedica a refletir o livro de Rafael Rosa Hagemeyer, História \& Audiovisual, publicado pela coleção História \& ... Reflexões, da Autêntica Editora. Evocando sua complexidade desde o início do livro, o autor se esmera em apontar as diferentes formas como estes objetos - televisão, cinema, animação, videogame, Recebido em: 14/10/2013 Aprovado em: 28/10/2013 
clipes, etc. - foram contemplados nos debates promovidos no âmbito das ciências humanas e sociais. Associado a essa preocupação, percebe-se o cuidado do autor em utilizar as experiências vividas no Laboratório de Imagem e Som do Curso de História da Universidade do Estado de Santa Catarina (UDESC), um observatório privilegiado para o pesquisador, como referencial para se discuti e visualizar as formas atuais de "dar forma audiovisual ao conhecimento histórico". (HAGEMEYER, 2012, p.13)

Trata-se de um livro compacto, dividido em três partes equilibradas tanto na densidade das reflexões desenvolvidas, quanto no número de páginas dedicadas a cada uma, aspecto importante para uma coleção que pretende abordar de forma introdutória temáticas téorico-conceituais ou metodológicas do campo da História.

Na primeira parte Hagemeyer realiza uma exposição sobre as mutações nas formas de compreensão das imagens e, posteriormente, dos registros audiovisuais contemplando os diferentes argumentos empregados por intelectuais, religiosos, artistas, filósofos, políticos - de "artifício fantasioso" a produto da indústria cultural contemporânea - para sua execração e crítica. Destaca-se o processo de construção de um aparato teórico metodológico capaz de suprimir essa aura negativa e conferir-lhes um estatuto senão de "verdade", mas o reconhecimento do potencial que os registros audiovisuais possuem para a produção de uma forma de conhecimento sobre a realidade, por meio de uma linguagem específica e em conformidade com as peculiaridades do contexto histórico em que tais produtos culturais estão imersos.

Percebe-se uma alteração importante no foco analítico, uma vez que ao contempla essa dimensão os registros audiovisuai passam do terreno da "ilusão" para serem analisados não só como uma forma de interpretação da História, mas como uma "construção imaginativa" derivada do encadeamento entre som, imagem, texto e movimento.

Outro aspecto relevante discutido nesse capítulo refere-se às possibilidades metodológicas oferecidas pelas teorias da linguagem para conferir o rigor almejado pelos críticos mais aguçados. Para além de uma crítica metodológica, o tópico em questão se destaca por sinalizar, de forma incisiva, sobre a exigência de se considerar os elementos múltiplos que integram a imagem audiovisual como a duração, a plasticidade, som, e como esses elementos são utilizados para produzir a narrativa almejada.

O segundo capítulo do livro contempla "as diferentes tecnologias que historicamente influenciaram o desenvolvimento de suas linguagens" (HAGEMEYER, 2012, p 60). Nesse caso, nos disserta sobre as metamorfoses na produção das imagens que garantiram a nossa entrada na "Era Paradoxal" (VIRILLO, 1988), época em que a virtualidade das imagens não só domina a atualidade como altera a noção de realidade. Com a virtualidade os audiovisuais se integram ao nosso cotidiano, interferindo não só nas formas de percepção da realidade - continuamente nos alimentamos de simulacros do real -, mas comprometendo sobretudo nossa relação com a realidade, na função dupla de mediar a interação com o real e de diluir as diferenças sociais, forjando uma identidade social.

O capítulo terceiro explora as diferentes "formas de narrativa histórica presente nos audiovisuais" (HAGEMEYER, 2012, p.12) Nesse caso, o seu olhar foi para dois pontos: 1) como os gêneros - discursivo, ficcional ou documentário - aplicados à narrativa audiovisual interferem na produção de sentido; 2) as possibilidades de expressão audiovisual do conhecimento histórico. Em sua análise, o autor intercede a favor da possibilidade da recriação ficcional do passado através do audiovisual como parte do exercício do historiador, sem que isso se torne num processo de modelagem da história em imagens, tal como preconizado de forma ousada por Robert Rosentone, citado pelo autor.

Para alicerçar sua defesa explora o conceito de "historiofotia", cunhado por Hayden White (1995) e o "poder de evocação" do passado que algumas fusões de imagens e sons produzem. Se opõe, assim, a antinomia cerrada entre "o padrão de estrutura formal acadêmica e o registro audiovisual" amalgamando os opostos (HAGEMEYER, 2012, p.149).

Ao final da leitura nós historiadores nos deparamos com o convite/provocação do autor pela utilização dos registros audiovisuais como um componente a mais na narrativa histórica, sem perder de vista o fato de que se trata de um processo de recriação de um acontecimento (que passa a existir a partir do momento em que é dado a conhecer).

Rastros, vestígios, indícios, registros... plurais foram as definições evocadas para caracterizar as imagens (visuais e audiovisuais) como outra forma de linguagem simbólica e dotada de múltiplos sentidos em conformidade com as formas e os suportes empregados para lhes dar sentido. Atualmente, já não precisamos nos empenhar com o mesmo ímpeto aguerrido na justificativa dos registros visuais como fontes latentes para a lide do historiador. Os diferentes usos e a intrínseca relação dos registros audiovisuais com as práticas cotidianas nos apresentam mais uma forma de promover uma presentificação da história, que passa a se constituir sobretudo em experiências regidas pelas potencialidades (limitadas) da arte.

\section{Referências Bibliográficas}

CERTEAU, Michel. A Invenção do Cotidiano: artes de fazer. RJ: Vozes, 1994

HAGEMEYER, Rafael Rosa. Historia \& Audiovisual. Belo Horizonte: Autêntica Editora, 2012.

VIRILLO, Paul. A Máquina da Visão. SP: José Olympio, 1994

WHITE, Hayden. Trópicos do Discurso: ensaios sobre a crítica da cultura. SP: EDUSP, 1995. 